удк 615.014.41:612.647.014.3:611.018.46

А.Н. Гольцев* , Т.Г. Дубрава, Ю.А. Гаевская,

Е.Е. Ямпольская, Л.В. Останкова, М.В. Останков

Особенности изменения структурно-функциональных

характеристик стволовых кроветворных клеток из разных

источников после криоконсервирования

UDC 615.014.41:612.647.014.3:611.018.46

A.N. Goltsev*, T.G. Dubrava, Yu.A. Gaevskaya,

E.E. Yampolskaya, L.V. Ostankova, M.V. Ostankov

\title{
in Structural and Functional Characteristics of Hematopoietic Stem Cells Derived from Various Sources
}

\begin{abstract}
Реферат: Проведенный сравнительный анализ структурно-функционального статуса стволовых кроветворных клеток (СКК) фетальной печени (ФП) 14 суток гестации и взрослого костного мозга (КМ) мышей линии СВА/Н 4-месячного возраста продемонстрировал не только различия их исходных качественно-количественных характеристик, но и разный ответ на действие фракторов криоконсервирования. Клетки ФП или КМ замораживали по разным режимам под защитой 5 и $10 \%$ диметилсульфоксида. Для оценки структурно-фрункциональных характеристик СКК из разных источников использовали методы цитофлуориметрии (содержание CD34+CD38--клеток), колониеобразования in vivo (KOEc) и in vitro (KOE-ГM). Установлено, что определенные режимы криоконсервирования способны проявлять эффект селективного обогащения популяций клеток с фенотипическими признаками кроветворных предшественников (CD34+CD38--клетки). Сопоставление содержания KОЕс, KОЕ-ГМ, СКК и клеток с фенотипом CD34 ${ }^{+} \mathrm{CD} 38^{-}$показало, что режим криоконсервирования для клеток ФП не является «оптимальным» для КМ. Показано, что при варьировании условий криоконсервирования можно обеспечивать не только «оптимальную» сохранность кроветворных предшественников из ФП и КМ с разным исходным функциональным статусом, но и направленно регулировать его.
\end{abstract}

Ключевые слова: криоконсервирование, фетальная печень, клетки костного мозга, стволовые кроветворные клетки.

Реферат: Проведений порівняльний аналіз структурно-функціонального статусу стовбурових кровотвірних клітин (СКК) фетальної печінки (ФП) 14-ї доби гестації та дорослого кісткового мозку (КМ) мишей лінії СВА/Н 4-місячного віку продемонстрував не тільки відмінності їхніх вихідних якісно-кількісних характеристик, але й різну відповідь на дію чинників кріоконсервування. Клітини ФП або КМ заморожували за різними режимами під захистом 5 і 10\% диметилсульфоксиду. Для оцінки структурно-фрункціональних характеристик СКК із різних джерел використовували методи цитофлуориметрії (вміст CD34 ${ }^{+} \mathrm{CD} 38^{-}-$-клітин), колонієутворювання in vivo (КУОс) та in vitro (КУО-ГМ). Встановлено, що певні режими кріоконсервування здатні виявляти ефект селективного збагачення популяцій клітин із фенотиповими ознаками кровотвірних попередників (CD34+CD38--клітини). Зіставлення вмісту KОЕс, КУО-ГМ, СКК та клітин із фенотипом CD34+CD38- показало, що режим кріоконсервування для клітин ФП не є «оптимальним» для КМ. Показано, що при варіюванні умов кріоконсервування можна забезпечувати не тільки «оптимальну» збереженість кровотвірних попередників із ФП та КМ і різним вихідним функціональним статусом, а й направлено регулювати його.

Ключові слова: кріоконсервування, фетальна печінка, клітини кісткового мозку, стовбурові кровотвірні клітини.

Abstract: The performed comparative analysis of structural and functional status of fetal liver (FL) hematopoietic stem cells (HSCs) of 14 gestation days and adult bone marrow (BM) of 4-month-old CBA/H mice demonstrated not only the differences of their initial qualitative and quantitative characteristics but also different responses to the effect of cryopreservation factors. Either FL or BM cells were frozen according to various regimens under protection of 5 and $10 \%$ dimethyl sulfoxide. To estimate structural and functional characteristics of HSCs derived from different sources there were used cytofluorimetry (content of CD34 ${ }^{+} \mathrm{CD} 38^{-}$cells), methods of colony formation in vivo (CFUs) and in vitro (CFU-GM). It has been established that certain cryopreservation regimens are able to manifest the effect of selective enrichment of cell populations with phenotype of hemopoietic progenitors $\left(\mathrm{CD} 34^{+} \mathrm{CD} 38^{-}\right.$cells). Comparing the content of CFUs, CFU-GM, HSCs and cells with CD34+CD38- phenotype has shown that cryopreservation regimen for FL cells was not optimal for BM. It has been demonstrated that varying cryopreservation conditions allowed not only to provide optimal preservation rate of hemopoietic progenitors derived from $\mathrm{FL}$ and BM with various initial functional status, but to control it purposefully.

Key words: cryopreservation, fetal liver, bone marrow cells, hemopoietic stem cells.

Отдел криопатофизиологии и иммунологии, Институт проблем криобиологии и криомедицины НАН Украины, г. Харьков

*Автор, которому необходимо направлять корреспонденцию: ул. Переяславская, 23, г. Харьков, Украина 61015; тел.: (+38 057) 373-57-91, факс: (+38 057) 373-30-84, электронная почта: cryopato@rambler.ru

Поступила 17.03.2014

Принята в печать 09.04.2014

Проблемы криобиологии и криомедицины.-2014.-Т. 24, №2. -С. 118-131. () 2014 Институт проблем криобиологии и криомедицины НАН Украинь
Department of Cryopathophysiology and Immunology, Institute for Problems of Cryobiology and Cryomedicine of the National Academy of Sciences of Ukraine, Kharkov, Ukraine

*To whom correspondence should be addressed:

23, Pereyaslavskaya str., Kharkov, Ukraine 61015; tel.:+380 57373 5791, fax: +380 573733084 , e-mail: cryopato@rambler.ru

Received March 17, 2014

Accepted April 9, 2014

Probl. Cryobiol. Cryomed. 2014. 24(2): 118-131.

(C) 2014 Institute for Problems of Cryobiology and Cryomedicine 
Длительное время трансплантация костного мозга (КМ) была безальтернативным методом лечения нарушений гемопоэза различного генеза $[22,34]$. В основе терапевтического эффекта донорского КМ лежат экспансия введенных стволовых кроветворных клеток (СКК) и репарация гемопоэтической системы реципиента $[1,16]$. Со временем для лечения патологий различного генеза стало возможным применение СКК из других источников, например, фетальной печени (ФП), кордовой крови и т. д. [3, 21], необходимость создания запасов которых предусматривает криоконсервирование, являющееся обязательным этапом применения такого рода тканевых субстратов в клинической практике [6, 29].

Многочисленные исследования показали, что криоконсервирование является не только методом долгосрочного хранения биообъекта, но и фактором управления его внутренним состоянием (intrinsic state) $[2,4,5]$. Причинами структурно-функциональных изменений СКК, вызванных криоконсервированием, могут быть кристаллообразование, изменение солевого градиента, $\mathrm{pH}$ среды, образование супероксидных радикалов и др. [9, 18]. Отмечено, что у криоконсервированных СКК временно снижается способность распознавать микроокружение и расселяться в нем вследствие шеддинга части поверхностных мембранных структур, определяющих их функциональный статус $[18,20]$. Установлена различная колониеобразующая способность СКК после криоконсервирования в зависимости от их нахождения в разных фазах клеточного цикла или стадии дифференцировки [8]. Отмеченные особенности структурно-функциональной организации СКК могут определять различную их криоустойчивость в зависимости от того, в каком гемопоэтическом плацдарме они функционируют, т. е. из какого источника получены $[19,21,24]$. По мнению некоторых исследователей, СКК костного мозга, формирующие колонии в селезенке летально облученных реципиентов, уже продвинуты в дифференцировке по сравнению с более потентными СКК фетальной печени [17, 23, 27]. Кроме того, по мере дифференцировки СКК меняют фенотипический репертуар и степень экспрессии различных мембранных молекул, определяющих их хоуминг и ряд других характеристик при введении реципиентам $[6,18]$. При адаптации к условиям микроокружения и ответе на местные регуляторные сигналы, донорские СКК могут не только изменять свой статус под их влиянием, но и выступать в роли модификатора этого микроокружения и в целом состояния гемопоэтического плацдарма реципиента, продуцируя регуляторные медиаторы с паракринной активностью [15]. Пластичность и
For a long time the transplantation of bone marrow (BM) was the only method to treat disorders in hematopoiesis of different genesis $[17,32]$. The basis of therapeutic effect of donor BM is the expansion of the introduced hematopoietic stem cells (HSCs) and reparation of recipient's hematopoietic system [2,33]. With the course of time the treatment of pathologies of different genesis became possible by applying the HSCs from other sources, e. g. fetal liver (FL), cord blood etc. $[7,15]$, the necessity to create their stocks requires cryopreservation, being consequently a mandatory stage for using such a tissue substrate in clinical practice $[12,26]$.

Numerous studies showed that cryopreservation could be not only a method for long-term storage of biological object, but a factor controlling its intrinsic state as well $[6,8,11]$. The causes of structural and functional changes in HSCs provided by cryopreservation can be crystal formation, change of saline gradient, medium $\mathrm{pH}$, formation of superoxide radicals etc. $[5,16]$. There was a notion that cryopreserved HSCs had a decreased ability to recognize microenvironment and populate it due to shedding of some surface membrane structures determining their functional status [5, 14]. Various colony-forming activities of HSCs were found following cryopreservation depending on their being in different phases of cell cycle or differentiation [3]. The revealed peculiarities of HSCs structure-functional organization may determine their different cryoresistance depending on the hemopoietic environment wherein they function, $i$. e. which source they are obtained from $[9,15,20]$. Some scientists suggest that BM HSCs forming the colonies in lethally irradiated recipients have already been advanced in differentiation as compared to the more potent FL HSCs [4, 19, 23]. Furthermore, as far as differentiation proceeds, the HSCs change their phenotype repertoir and expression rate of various membrane molecules determining their homing and other characteristics following introduction to recipients [5, 12]. During adapting to microenvironment conditions and response to local regulatory signals, donor HSCs can change their status under that influence as well as function as modifier of the microenvironment and in a whole of the state of recipient's hematopoietic environment produ-cing regulatory mediators with a paracrine activity [1]. Flexibility and variety of structural and functional characteristics of bone marrow and fetal liver HSCs a priori make them an extraordinary target for physical and chemical factors implemented during cryopreservation. Thus, an initial state of HSCs can determine a functional activity of the frozen-thawed specimens used in clinical practice, which include these cells.

The use of HSCs of various sources to treat autoimmune diseases including BM and FL necessitates the 
широта структурно-функциональных характеристик СКК костного мозга и фетальной печени a priori делают их неординарной мишенью для физико-химических факторов, реализуемых в процессе криоконсервирования. Таким образом, исходное состояние СКК может определять функциональную активность используемого в клинической практике деконсервированного материала, в состав которого они входят.

Применение СКК из различных источников при лечении аутоиммунных заболеваниях, в том числе из КМ и ФП, обуславливает необходимость создания их запасов и поиска «оптимальных» методов криоконсервирования. В связи с этим актуальным как в теоретическом, так и прикладном аспектах остается изучение криолабильности СКК из разных источников с целью разработки «оптимальных» режимов их криоконсервирования.

Цель данной работы - провести сравнительный анализ влияния различных условий криоконсервирования на структурно-функциональное состояние СКК фетальной печени и взрослого костного мозга.

\section{Материалы и методы}

Эксперименты выполняли на мышах линии CBA/H 4-месячного возраста массой 20-25 г, содержащився в стандартных условиях вивария Института проблем криобиологии и криомедицины НАН Украины (г. Харьков). Исследования проводили в соответствии с «Общими принципами экспериментов на животных», одобренными III Национальным конгрессом по биоэтике (г. Киев, 2007) и согласованными с положениями «Европейской конвенции о защите позвоночных животных, используемых для экспериментальных и других научных целей» (г. Страсбург, 1986).

Животных декапитировали под легким эфирным наркозом. Фетальную печень, выделенную из эмбрионов на 14-й посткоитальный день, дезинтегрировали в гомогенизаторе Поттера в среде 199 (Институт полиомиелита и вирусных энцефалитов, Россия) с добавлением 10\%-й эмбриональной телячьей сыворотки («БиолоТ», Россия) и 2\%-го цитрата натрия (далее в тексте - рабочая среда) с последующей очисткой через капроновый фильтр для удаления конгломератов.

Клетки КМ вымывали из бедренных костей рабочей средой. Однородную суспензию клеток получали путем многократного пропускания через иглы уменьшающегося диаметра (0,8-0,5 мм) и капроновый фильтр.

Раствор для криоконсервирования клеток ФП и КМ представлял собой рабочую среду с 10 или 20\% диметилсульфоксида (ДМСО) («Артериум», Украина). К полученным на рабочей среде суспен- establishing of their stocks and search for 'optimal' cryopreservation methods. Herewith relevant in both theoretical and practical aspects is the studying of cryolability in HSCs from different sources in order to develop 'optimal' regimens for their cryopreservation.

The objective of this research was to perform a comparative analysis of the effect of different cryopreservation conditions on structure-functional state of fetal liver and adult bone marrow HSCs.

\section{Materials and methods}

The experiments were carried out in 4-month-old CBA/H mice of 20-25 g weight kept under standard conditions of the vivarium at the Institute for Problems of Cryobiology and Cryomedicine of the National Academy of Sciences of Ukraine (Kharkov). The studies were performed according to the General Principles of the Experiments in Animals approved by the $3^{\text {rd }}$ National Congress on Bioethics (Kiev, 2007) and consistent with the regulations of European Convention for the Protection of Vertebrate Animals used for Experimental and other Scientific Purposes (Strasbourg, 1986).

The animals were decapitated under light ether anaesthesia. Fetal liver isolated from the embryos to the $14^{\text {th }}$ post-coital day, was pounded in Potter homogenizer in 199 medium (Institute of Poliomyelitis and Viral Encephalitides, Russia) supplemented with 10\% fetal bovine serum (Biolot, Russia) and 2\% sodium citrate (hereinafter handling medium) with the following purification through a nylon filter to remove conglomerates.

BM cells were washed out of femur bones with the handling medium. Homogeneous suspension was derived by repeated passage through needles of decreasing diameter $(0.8-0.5 \mathrm{~mm})$ and nylon filter.

The solution for cryopreservation of FL and BM cells was the handling medium with 10 or $20 \%$ dimethyl sulfoxide (DMSO) (Arterium, Ukraine). The obtained with handling medium suspension of FL and BM cells was dropwise supplemented with cryoprotective solution in $1: 1$ ratio at $18^{\circ} \mathrm{C}$ during $2 \mathrm{~min}$ (final concentration of cryoprotectant made 5 and 10\%). Cells were exposed in solution for $10 \mathrm{~min}$ at the same temperature. Cells of FL and BM with the concentration of $6.0 \times 10^{6}$ cells $/ \mathrm{ml}$ and volume of $1.0 \mathrm{ml}$ were frozen with programmable freezer UOP-6 produced by Special Designing and Technical Bureau with Experimental Unit (IPC\&C of the NAS of Ukraine, Kharkov) in plastic ampoules (Nunc, Germany) by the following regimens:

- Regimen 1 (R1) was the cooling from room temperature down to $-40^{\circ} \mathrm{C}$ with the cooling rate of $1 \mathrm{deg} / \mathrm{min}$ with 5\% DMSO (freezing program was developed for BM cells) [26]; 
зиям клеток ФП или КМ по каплям добавляли криоконсервирующий раствор в соотношении 1:1 при температуре $18^{\circ} \mathrm{C}$ в течение 2 мин (конечная концентрация криопротектора составила 5 и 10\%). Экспозицию клеток в растворе проводили в течение 10 мин при той же температуре. Клетки ФП или КМ с концентрацией $6,0 \times 10^{6}$ кл/мл и объемом 1,0 мл замораживали на программном замораживателе УОП-6 (СКТБ с ОП ИПКиК НАН Украины, Харьков) в пластиковых ампулах («Nunc», Германия) по следующим режимам:

- режим 1 (P1) - замораживание от комнатной температуры до $-40^{\circ} \mathrm{C}$ со скоростью 1 град/мин с 5\% ДМСО (программа замораживания разработана для клеток КМ) [29],

- режим 2 (P2) - замораживание от комнатной температуры до $-40^{\circ} \mathrm{C}$ со скоростью 1 град/мин с 10\% ДМСО (программа замораживания разработана для клеток КМ) [29],

- режим 3 (P3) - замораживание от комнатной температуры до $-40^{\circ} \mathrm{C}$ со скоростью 1 град/мин, 10минутная выдержка, затем охлаждение при 10 град/мин до $-80^{\circ} \mathrm{C}$ с 5\% ДМСО (программа замораживания разработана для клеток ФП) [13],

- режим 4 (P4) - замораживание от комнатной температуры до $-40^{\circ} \mathrm{C}$ со скоростью 1 град/мин, 10минутная выдержка, затем охлаждение при 10 град/мин до $-80^{\circ} \mathrm{C}$ с $10 \%$ ДМСО с последующим погружением ампул в каждом случае в жидкий азот (программа замораживания разработана для клеток ФП) [13].

Оттаивание образцов проводили на водяной бане при температуре $38 \ldots 40^{\circ} \mathrm{C}$ до исчезновения твердой фазы. Клетки однократно отмывали от ДМСО путем покапельного добавления равного объема рабочей среды, затем центрифугировали (200g, 10 мин). Суспензии клеток, не подвергавшиеся процедуре замораживания-отогрева, далее будем называть нативным контролем.

Сохранность клеток до и после криоконсервирования определяли с помощью пропидий йодида («Sigma», США) на проточном цитофлуориметре «FACS Calibur» («Becton Dickinson», СШA), количество ядросодержащих клеток - в камере Горяева.

Фенотипический анализ клеток осуществляли на проточном цитофлуориметре «FACS Calibur» («Becton Dickinson»), используя моноклональные антимышиные антитела к мембранным маркерам CKK: CD34 (PE, «BD Biosciences», США), CD38 (FITC, «BD Biosciences») согласно инструкции производителя. В качестве контроля использовали пробы с добавлением неиммунных меченных FITC и PE моноклональных антител («BD Biosciences»)
- Regimen 2 (R2) comprised cooling from room temperature down to $-40^{\circ} \mathrm{C}$ with the rate of $1 \mathrm{deg} / \mathrm{min}$ with 10\% DMSO (freezing program was developed for BM cells) [26],

- Regimen 3 (R3) utilized cooling from room temperature down to $-40^{\circ} \mathrm{C}$ with the rate of $1 \mathrm{deg} / \mathrm{min}$, 10 -min pause, then cooling with $10 \mathrm{deg} / \mathrm{min}$ rate down to $-80^{\circ} \mathrm{C}$ with $5 \%$ DMSO (freezing program was developed for FL cells) [35],

- Regimen 4 (R4) was the cooling from room temperature down to $-40^{\circ} \mathrm{C}$ with the rate of $1 \mathrm{deg} / \mathrm{min}$, 10 -min pause, then cooling with $10 \mathrm{deg} / \mathrm{min}$ rate down to $-80^{\circ} \mathrm{C}$ with $10 \% \mathrm{DMSO}$ with the following plunging of ampoules in each case in liquid nitrogen (freezing program was developed for FL cells) [35].

Samples were thawed in water bath at $38 \ldots 40^{\circ} \mathrm{C}$ until disappearance of solid phase. Cells were onefold washed from DMSO by dropwise addition of handling medium of equal volume, then centrifuged (200g, $10 \mathrm{~min}$ ). Cell suspension not subjected to freezethawing we will refer to the native control.

Cell survival prior to and after cryopreservation was determined using propidium iodide (Sigma, USA) with flow cytometer FACS Calibur (Becton Dickinson, USA), number of nucleated cells was calculated in Goryaev's chamber.

Phenotype analysis of cells was performed with flow cytometer FACS Calibur (Becton Dickinson, USA) using monoclonal anti-mouse antibodies to membrane markers of HSCs: CD34 (PE, BD Biosciences, USA), CD38 (FITC, BD Biosciences, USA) according to the manufacturer's instructions. As the control we used the samples with addition of non-immune FITC and PE marked monoclonal antibodies (BD Biosciences) of the same isotype as antibodies against the studied marker.

Mean fluorescence intensity (MFI) by CD34 marker of FL and BM cells was determined with flow cytometer FACS Calibur (Becton Dickinson) [10]. Using logarithmic scale with a signal intensity within the range of 64-1024 channels we measured MFI by CD34 marker and expressed it in arbitrary units corresponding to the median channel of marker's maximum lumines-cence. To minimize the errors in the samples we analyzed 10,000 events. The data were statistically processed with WinMDI 2.8 software.

The content of colony-forming units in spleen of lethally irradiated recipients (sCFU) was assessed in vivo by standard method [31]. Native control (nFL and $\mathrm{nBM}$ ) and cryopreserved (cFL and $\mathrm{cBM}$ ) cell suspensions in the dose of $1 \times 10^{5}$ cells/mouse $(0.2 \mathrm{ml})$ were injected into tail vein of recipient mice irradiated by RUM-17 (Mosrentgen, Russia) in $850 \mathrm{R}$ dose. Irradiation conditions: dose power was $38.6 \mathrm{R} / \mathrm{min}$, 
того же изотипа, что и антитела к исследуемому маркеру.

Среднюю интенсивность флуоресценции (СИФ) по CD34 маркеру клеток ФП и КМ определяли на проточном цитофлуориметре «FACS Calibur» («Becton Dickinson») [14]. По логарифмической шкале с интенсивностью сигнала в диапазоне от 64 до 1024 канала измеряли СИФ по CD34 маркеру и выражали его в условных единицах, соответствующих среднему каналу максимального свечения маркера. Для минимизации ошибок в пробах анализировали 10000 событий. Статистический учет данных осуществляли с помощью программы «WinMDI 2.8».

Оценку содержания колониеобразующих единиц в селезенке летально облученных реципиентов (KOEc) in vivo осуществляли общепринятым методом [33]. Нативные контрольные (нФП и нКМ) и криоконсервированные (кФП и кКМ) клеточные суспензии в дозе $1 \times 10^{5}$ кл/мышь (0,2 мл) вводили в хвостовую вену мышам-реципиентам, облученным на установке РУМ-17 («Мосрентген», Россия) в дозе 850 Р. Условия облучения: мощность дозы - 38,6 Р/мин, напряжение - 220 кВ, сила тока 10 мА, фильтры - 1 мм $\mathrm{Cu}+1$ мм Al; фокуснодорзальное расстояние - 50 см. Мышей облучали в коробке из оргстекла с индивидуальными ячейками для каждого грызуна. После облучения экспериментальные животные в течение 2 недель получали антибиотик «Энроксил» («KRKA», Словения) и молочную сыворотку. Количество КОЕс учитывали по числу колоний, образованных в селезенках летально облученных реципиентов на 14-е сутки после введения исследуемых клеточных суспензий.

Содержание кроветворных предшественников грануломоноцитопоэза (КОЕ-ГМ) in vitro определяли по количеству колониеобразующих единиц (КОЕ) и кластерообразующих единиц (КлОЕ) в полужидком агаре. Клетки культивировали в концентрации $1 \times 10^{5}$ кл/мл при температуре $37^{\circ} \mathrm{C}$ в атмосфере $5 \% \mathrm{CO}_{2}$ и 95\%-й влажности воздуха [12]. В нативном материале их идентифицировали на 7-е сутки культивирования, в криоконсервированном - на 14-е сутки, поскольку пролиферативная активность КОЕ-ГМ была временно ингибирована под действием криоконсервирования [8]. Количество агрегатов, сформированных КОЕ-ГМ, подсчитывали под инвертированным микроскопом (×40). Интегральный показатель КОЕ-ГМ представлял собой сумму кластеров, содержащих до 20 клеток, и колоний - более 20 клеток. Для оценки особенностей распределения кроветворных клеток различной степени дифференцировки был введен индекс пролиферативной активности (ИПА) отношение КОЕ к КлОЕ. voltage $220 \mathrm{kV}$, current intensity $10 \mathrm{~mA}$, filters $1 \mathrm{~mm}$ $\mathrm{Cu}+1 \mathrm{~mm} \mathrm{Al}$; focal dorsal length $50 \mathrm{~cm}$. Mice were irradiated in the box made of organic glass with separate wells for each rodent. Experimental animals received Enroxil (KRKA, Slovenia) and whey during 2 weeks after irradiation. Number of sCFUs was calculated by the number of colonies formed in spleens of lethally irradiated recipients on the $14^{\text {th }}$ day after administration of the studied cell suspensions.

Content of hematopoietic progenitors of granulomonocytopoiesis (CFU-GM) was determined in vitro by the number of colony-forming units (CFU) and clusterforming units (ClFU) in semisolid agar. Cells were cultured in the concentration of $1 \times 10^{5} \mathrm{cells} / \mathrm{ml}$ at $37^{\circ} \mathrm{C}$ in the atmosphere with $5 \% \mathrm{CO}_{2}$ and $95 \%$ air humidity [28]. In native material they were identified to the $7^{\text {th }}$ day of culture, and to the $14^{\text {th }}$ day in cryopreserved one since the proliferative activity of CFU-GM was temporarily inhibited under effect of cryopreservation [3]. Number of aggregates formed by CFU-GM was counted with inverted microscope $(\times 40)$. Integral index of CFU-GM was the sum of clusters containing up to 20 cells and colonies - more than 20 cells. To assess the peculiarities of distribution of hematopoietic cells of various differentiation degrees we used the proliferative activity index (PAI) which is the ratio of CFU to ClFU.

The obtained data were statistically processed by Student's t-test using Excel (MS, USA). The data are presented as mean \pm standard error. The differences were considered significant at $p<0.05$.

\section{Results and discussion}

The results of assessing survival and quantitative content of nucleated cells in FL and adult BM after cryopreservation under different regimens are presented in Fig. 1. Significant differences of the studied indices were obvious when using the same cryopreservation regimens for FL and BM. Maximum indices of survival and number of nucleated cells were obtained under R3 for FL cells and R2 for BM (Fig. 1).

Key element in formation and providing the functional status of hematopoietic system is the population of HSCs capable to intensive proliferation and differentiation. The most known phenotype marker of HSCs is membrane structure, CD34-sialomucin, its function consists in interaction of earlier hematopoiesis progenitors with BM stroma involving $L$-selectin adhesion molecule. During committing of hematopoietic progenitors the level of CD34 antigen expression decreases with the simultaneous increase of differentiation antigen CD38 expression [21]. So, CD $34^{+} \mathrm{CD} 38^{-}$cells tend to be highly potent HSCs while subpopulation of $\mathrm{CD} 4^{+}$ CD $38^{-}$is represented by progenitors with restricted differentiation potential.

Our results indicate a different character of change in the content of $\mathrm{CD}_{3} 4^{+} \mathrm{CD} 38^{-}$cells in $\mathrm{BM}$ and $\mathrm{FL}$ 
Полученные данные статистически обрабатывали по методу Стьюдента с применением компьютерной программы «Excel» («MS», США). Данные приведены в виде среднего значения \pm стандартное отклонение. Различия считали статистически значимыми при $p<0,05$.

\section{Результаты и обсуждение}

Результаты оценки сохранности и количественного содержания ядросодержащих клеток в ФП и взрослом КМ после криоконсервирования в различных режимах представлены на рис.1. Очевидны существенные различия исследуемых показателей при использовании одних и тех же режимов криоконсервирования для клеток ФП и КМ. Максимальные показатели сохранности и количества ядросодержащих клеток были получены при использовании Р3 для клеток ФП и Р2 - для КМ (рис. 1).

Ключевым элементом формирования и обеспечения функционального статуса гемопоэтической системы является популяция СКК, способная к интенсивной пролиферации и дифференцировке. Наиболее известным фенотипическим маркером СКК является мембранная структура CD34-сиаломуцин, функция которой заключается во взаимодействии ранних предшественников гемопоэза со стромой КМ при участии молекулы адгезии $L$-селектина. По мере коммитирования гемопоэтических предшественников уровень экспрессии CD34-антигена снижается с одновременным увеличением экспрессии дифференцировочного антигена CD38 [25]. Таким образом, на роль высокопотентных СКК претендуют $\mathrm{CD} 34^{+} \mathrm{CD} 38^{-}$-клетки, в то время как субпопуляция клеток $\mathrm{CD} 34^{+} \mathrm{CD} 38^{+}$ представлена предшественниками с ограниченным дифференцировочным потенциалом.

Полученные нами результаты свидетельствуют о разном характере изменения содержания $\mathrm{CD} 34^{+} \mathrm{CD} 38^{-}$-клеток в КМ и ФП после криоконсервирования (рис. 2). Так, для ФП содержание $\mathrm{CD} 34^{+} \mathrm{CD} 38^{-}$-клеток значимо увеличивалось по сравнению с нативным контролем только при использовании Р3. При замораживании КМ по всем режимам увеличивалось количество клеток с фенотипом $\mathrm{CD} 34^{+} \mathrm{CD} 38^{-}$, причем максимально при Р2. Кроме того, на примере использования Р2 видно, что содержание $\mathrm{CD} 34^{+} \mathrm{CD} 38^{-}$-клеток в КМ повышалось, в то время как в ФП - снижалось по сравнению с соответствующим нативным контролем. Уменьшение количества CD $34^{+} \mathrm{CD} 38^{-}$-клеток после криоконсервирования в ФП при использовании Р2, по-видимому, можно объяснить гибелью части клеток, экспрессирующих маркер CD34 (гибель общей популяции клеток ФП составила
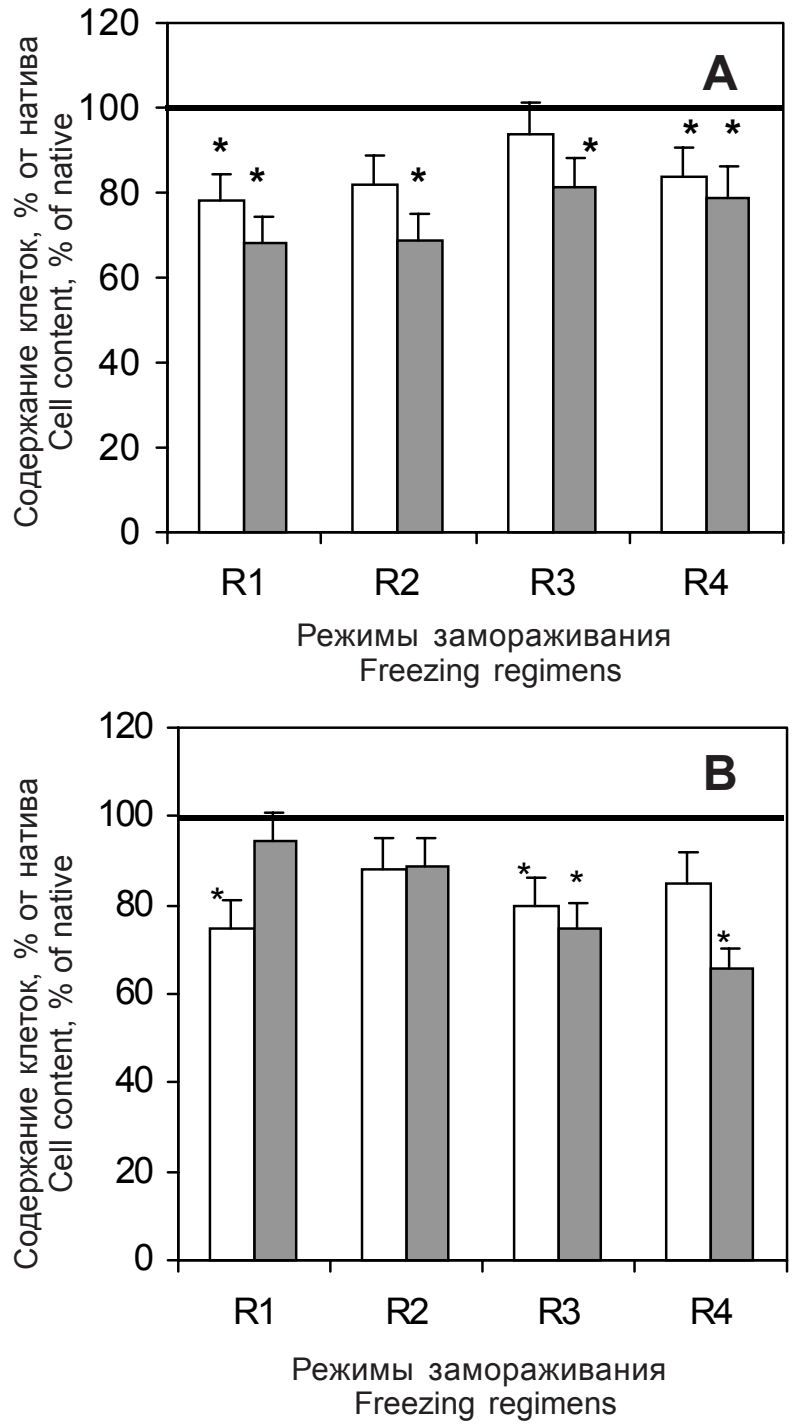

Рис. 1. Содержание сохранных и ядросодержащих клеток в суспензиях ФП (А) и КМ (В) после криоконсервирования по разным режимам ( $R-$ режим): $\square-$ количество сохранных клеток; $\square$ - количество ядросодержащих клеток; за $100 \%$ принят показатель нативного материала; * - различия значимы по отношению к соответствующему нативному контролю, $p<0,05$.

Fig. 1. Content of survived and nucleated cells in suspensions of $F L(A)$ and $B M(B)$ after cryopreservation according different regimens (R): $\square$ - content of survived cells; $\square-$ content of nucleated cells; the index of native material was assumed as $100 \%$; * - differences are significant in relation to the respective native control, $p<0.05$.

after cryopreservation (Fig. 2). In case of FL the content of $\mathrm{CD} 34^{+} \mathrm{CD} 38^{-}$cells significantly enhanced if compared with the native control only after using $\mathrm{R} 3$. When freezing BM under all the regimens the number of cells with phenotype $\mathrm{CD} 34^{+} \mathrm{CD} 38^{-}$increased, maximally after utilization of $\mathrm{R} 2$. In addition, $\mathrm{R} 2$ could be example for the notion that the content of CD34 ${ }^{+}$ $\mathrm{CD} 38^{-}$cells in BM increased while in FL it lowered as compared with the respective native control. Dec- 

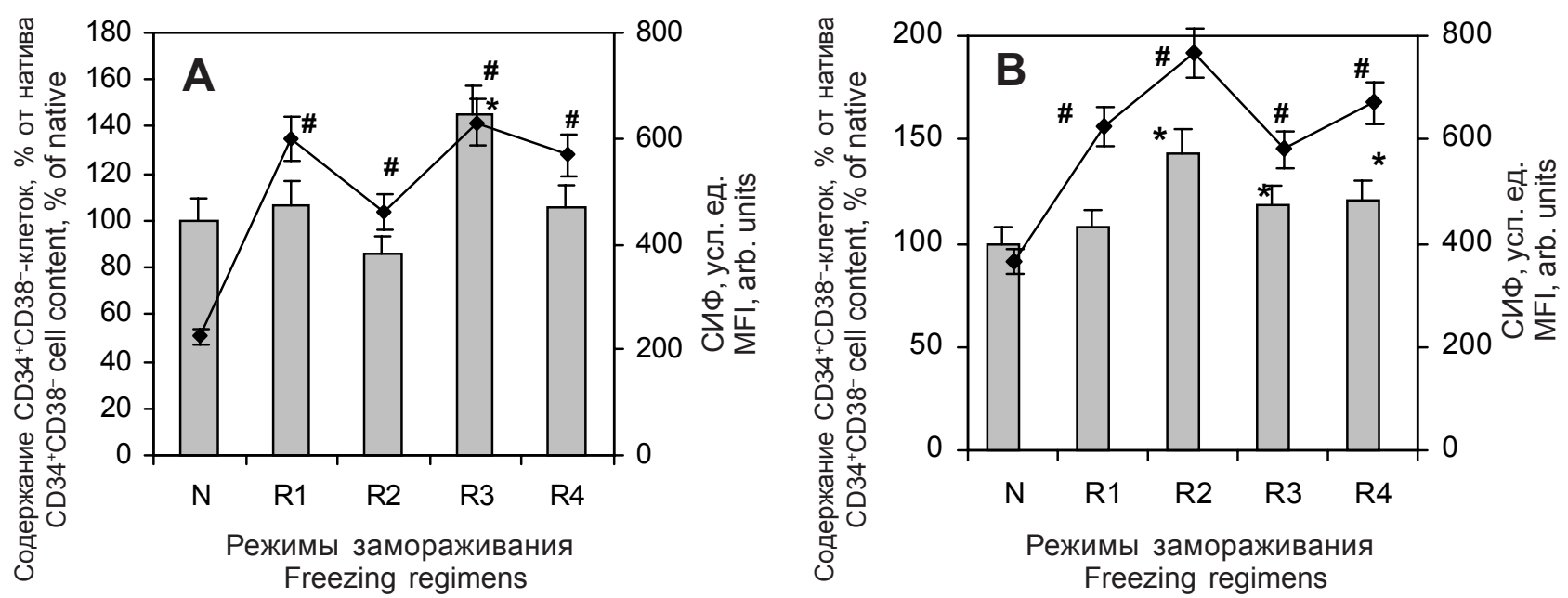

Рис. 2. Содержание $\mathrm{CD} 34^{+} \mathrm{CD} 38^{-}-$-клеток (столбцы) и их СИФ (по CD34-маркеру, линия) в ФП (A) и КМ (B) после криоконсервирования по разным режимам; R - режим; N - натив; за $100 \%$ принято количество колоний, формируемых нативными клетками ФП и КМ; *, \#- различия значимы по отношению к соответствующему нативному контролю, $p<0,05$.

Fig. 2. Content of $\mathrm{CD} 34^{+} \mathrm{CD} 38^{-}$-cells (columns) and their MFI (by CD34 marker, line) in FL (A) and BM (B) after cryopreservation under different regimens $(R) ; \mathrm{N}$ - native; number of colonies formed by native cells of FL and BM were assumed as 100\%; ${ }^{*}, \#$ - differences are significant in relation to the respective native control, $p<0.05$.

31\%). Аналогичные результаты уменьшения количества CD34+-клеток уже на этапе эквилибрации с ДМСО и после криоконсервирования по вышеуказанному режиму были получены ранее [28]. В результате сравнительной оценки чувствительности к криоконсервированию субпопуляций $\mathrm{CD} 34^{+} \mathrm{CD} 38^{+}$ и $\mathrm{CD} 34^{+} \mathrm{CD} 38^{-}$гемопоэтических клеток КМ было установлено, что после криоконсервирования под защитой $10 \%$ ДМСО количество $\mathrm{CD} 34^{+} \mathrm{CD} 38^{+}$-клеток уменьшилось на $11,8 \%$, а $\mathrm{CD} 34^{+} \mathrm{CD} 38^{-}-$ значимо не изменилось [26]. Авторы сделали заключение, что более криоустойчивыми являются CD34+-клетки, которые не экспрессируют CD38антиген, что свидетельствует о способности менее коммитированных клеток-предшественников к восстановлению внутриклеточных повреждений, т. е. $\mathrm{CD} 34^{+} \mathrm{CD} 38^{-}$-клетки более толерантны к действию факторов криоконсервирования. Факт повышения концентрации данных клеток после замораживания-отогрева ФП по Р3 и КМ по Р2 не может быть объяснен перераспределением их субпопуляционного состава за счет гибели какойто части клеток. Процент погибших клеток после использования Р1 (см. рис. 1) и процент клеток с фенотипом $\mathrm{CD} 34^{+} \mathrm{CD} 38^{-}$(см. рис. 2) абсолютно несопоставимы: для ФП и КМ гибель составила 19 и $11,2 \%$ (содержание $\mathrm{CD} 34^{+} \mathrm{CD} 38^{-}$-клеток увеличилось на 44 и $43 \%$ соответственно). Одной из причин повышения концентрации СКК в суспензиях ФП и КМ после криоконсервирования по указанным режимам может быть экспрессия CD34-маркера на клетках, которые до криоконсервирования были reased number of $\mathrm{CD} 34^{+} \mathrm{CD} 38^{-}$cells after cryopreservation of FL under R2 apparently can be explained by death of the cells expressing CD34 marker (death of total population of FL cells was $31 \%$ ). Similar results on decreased number of $\mathrm{CD} 34^{+}$cells during equilibration with DMSO and following cryopreservation using the above mentioned regimen were described pre-viously [25]. Comparative assessing the sensitivity to cryopreservation of $\mathrm{CD} 34^{+} \mathrm{CD} 38^{+}$and $\mathrm{CD} 34^{+} \mathrm{CD} 38^{-}$ subpopulations of BM hematopoietic cells showed that following cryopreservation under 10\% DMSO protection the number of $\mathrm{CD} 34^{+} \mathrm{CD} 38^{+}$cells lowered by $11.8 \%$, and that of $\mathrm{CD} 34^{+} \mathrm{CD} 38^{-}$cells did not significantly change [22]. Authors came to the conclusion that the most cryoresistant were the $\mathrm{CD} 34^{+}$cells, which did not express CD38 antigen, that testified the ability of less committed progenitor cells to recover the intracellular damages, i.e. $\mathrm{CD} 34^{+} \mathrm{CD} 38^{-}$cells were more tolerant to the effect of cryopreservation factors. The increased concentration of these cells after freezethawing of FL under R3 and BM under R2 can not be explained by redistribution of their subpopulation content due to the death of the part of the cells. Percentage of dead cells after using R1 (see Fig. 1) and percentage of cells with $\mathrm{CD} 34^{+} \mathrm{CD} 38^{-}$phenotype (see Fig. 2) are incomparable because for FL and BM the death made 19 and $11.2 \%$ (the content of $\mathrm{CD} 34^{+} \mathrm{CD} 38^{-}$cells increased by 44 and $43 \%$, respectively). One of the reasons for increase of HSC concentration in FL and $\mathrm{BM}$ suspensions after cryopreservation under the mentioned regimens may be the expression of CD34 marker in the cells which prior to cryopreservation were 
«негативны» по нему, при этом интенсивность подобных модификаций определялась видом биоматериала. Степень изменения уровня экспрессии мембранных структур СКК в ответ на криовоздействие может зависеть и от вида рецепторов. Например, после криоконсервирования КМ количество Тhy-1,2+-клеток не превышало 15\% (исходное их содержание принято за 100\%), тогда как в популяции стволовых клеток, способных формировать КОЕс, - не более 6\% [33]. Известно, что рецептор Тhy-1,2 отвечает за хоуминг СКК, а его шеддинг после криоконсервирования может быть причиной более позднего расселения СКК в гемопоэтическом плацдарме после введения КМ [18]. Оценка содержания в КМ клеток, экспрессирующих рецептор Мас-1, показала уменьшение их количества после криоконсервирования [5]. Анализ экспрессии различных молекул адгезии на $\mathrm{CD} 34^{+}$клетках, выделенных из различных источников, также продемонстрировал значимое снижение экспресии молекулы $L$-selectin на CD34+-клетках, полученных из периферической крови, костного мозга и кордовой крови в 1,6; 4,4 и 3,5 раза соответственно [20]. Разная чувствительность к криоконсервированию рецепторов, отвечающих за межклеточные взаимодействия, экспериментально показана при оценке состояния КОЕ-ГМ клеток КМ. Эти клетки утрачивали чувствительность к колониестимулирующей активности кондиционной среды, сохраняя ее к факторам фидерного слоя после криоконсервирования [10].

Важным компонентом анализа состояния клеток методом проточной цитофлуориметрии является оценка интенсивности флуоресценции того или иного маркера с использованием показателя СИФ, который отражает функциональное состояние исследуемых клеток [14]. Установлено, что после криоконсервирования ФП и КМ по всем режимам СИФ маркера CD34 существенно превышала уровень нативного контроля. Необходимо отметить, что изменения СИФ и количества CD34+CD38-клеток были сходны. Максимальное увеличение СИФ по сравнению с нативным контролем наблюдали также при замораживании ФП по Р3 и КМ по P2. Таким образом, исходя из показателя СИФ, криоконсервирование оказывало существенное влияние как на количество клеток ФП и КМ с фенотипом CD $34^{+} \mathrm{CD} 38^{-}$, так и на их функциональную активность.

Известно, что терапевтический потенциал гемопоэтической ткани определяется функциональной активностью содержащихся в ней СКК, которую определяют методами колониеобразования in vivo и in vitro. Одним из методов является оценка способности СКК формировать колонии in vivo в селе- negative according to it, moreover intensity of these modifications was determined by the type of biological specimen. The extent of changes in expression level of HSC membrane structures in response to cryoexposure could also depend on the type of receptors. For example, following cryopreservation of BM the number of Thy $-1,2^{+}$cells did not exceed $15 \%$ (their initial content was defined as $100 \%$ ) whereas in population of stem cells able to form CFUs it was not more than $6 \%$ [31]. It is known that Thy- 1,2 receptor is responsible for HSCs homing, and its shedding after cryopreservation can be the cause for delayed population of HSCs in hematopoietic environment after BM cells introduction [5]. Assessing the content of cells in BM which expressed receptor Mac-1 showed a decreased number of these following cryopreservation [11]. Analysis of expression of different adhesion molecules in $\mathrm{CD} 4^{+}$cells isolated from various sources demonstrated a significant lowering in $L$-selectin expression in $\mathrm{CD}_{3} 4^{+}$cells derived from peripheral blood, bone marrow and cord blood: 1.6; 4.4 and 3.5 times, respectively [14]. Different sensitivity to cryopreservation of receptors responsible for cell-cell interactions was experimentally shown when assessing the state of CFU-GM in BM cells. These cells lost their sensitivity to colony-stimulating activity of conditioned medium, but preserved the response to the factors of feeder layer after cryopreservation [18].

An essential component in flow cytometry analysis of a cell state is the assessment of fluorescence intensity of various markers using MFI value which reflects functional state of the studied cells [10]. We have found that after cryopreservation of FL and BM under all the regimens MFI of CD34 marker significantly exceeded the level of native control. It should be noted that changes of MFI and number of $\mathrm{CD} 34^{+} \mathrm{CD} 38^{-}$cells were similar. Maximum increase of MFI compared with the native control was also observed following freezing of FL under R3 and BM under R2. Therefore, proceeding from the data of MFI index, the cryopreservation significantly influenced the number of FL and BM cells with phenotype $\mathrm{CD} 34^{+} \mathrm{CD} 38^{-}$as well as their functional activity.

It is known that a therapeutic potential of hematopoietic tissue is determined by functional activity of HSCs contained in it, which could be determined by colony formation in vitro and in vivo. One of the methods is the assessment of HSC ability to form colonies in vivo in spleen (CFUs) of lethally irradiated recipients [31]. Using this method we have established that cryopreservation according all the regimens caused the decrease of CFUs in fetal liver and bone marrow if compared with the native material (Fig. 3). Maximum survival of CFUs in FL and BM was provided by different cryopreservation regimens: $\mathrm{R} 3$ for $\mathrm{FL}$ and $\mathrm{R} 2$ for 

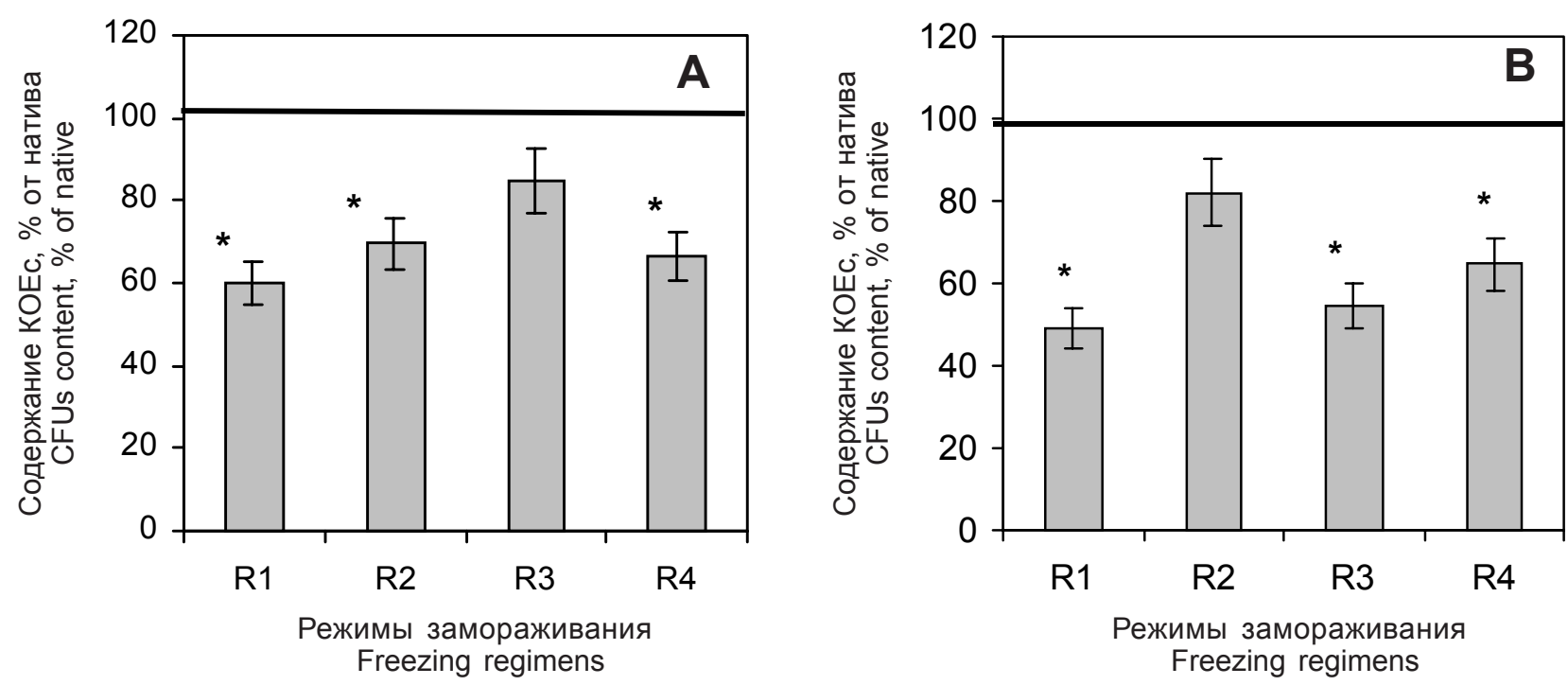

Рис. 3. Содержание КОЕс в ФП (А) и КМ (B) после криоконсервирования по разным режимам; $R$ - режим; за $100 \%$ принято количество колоний, формируемых нативными КОЕс ФП и КМ; * - различия значимы по отношению к соответствующему нативному контролю, $p<0,05$.

Fig. 3. Content of CFUs in FL (A) and BM (B) after cryopreservation under different regimens (R); number of colonies formed by native SCFU of FL and BM were assumed as 100\%; * - differences are significant in relation to the respective native control, $p<0.05$.

зенке (КОЕс) летально облученных реципиентов [33]. Используя данный метод, было установлено, что криоконсервирование во всех режимах вызывало снижение КОЕс фетальной печени и костного мозга по сравнению с нативным материалом (рис. 3). Максимальную сохранность КОЕс в ФП и КМ обеспечивали разные режимы криоконсервирования: Р3 для ФП и Р2 для КМ. Необходимо отметить, что колониеобразующая активность СКК in vivo после криоконсервирования не всегда соответствовала содержанию $\mathrm{CD} 34^{+} \mathrm{CD} 38^{-}$-клеток как в ФП, так и в КМ (см. рис. 2). Известно, что с 12 -х по 16-е сутки гестации ФП является основным органом гемопоэза, в котором происходят экспансия и дифференцировка гемопоэтических клеток [17]. В этот период в печени содержится большое количество long-term (LT-HSC) и short-term hematopoietic stem cells (ST-HSC), активность которых контролируется клеточным фактором Стила, гранулоцитарно-макрофагальным колониестимулирующим фактором и интерлекином-3, действующими в синергизме $[32,35]$. Высокий репликативный потенциал этих клеток, способность дифференцироваться в различные ростки кроветворения, защищать от гибели летально облученных реципиентов подтверждены результатами многих работ [23, 27, $31,35]$. Тем не менее, даже при одинаковой концентрации $\mathrm{CD} 34^{+} \mathrm{CD} 38^{-}$-клеток в нативных ФП $((0,35 \pm 0,02) \%)$ и КМ $((0,30 \pm 0,04) \%)$, колониеобразующий потенциал ФП был существенно ниже КМ $(4,31 \pm 0,57$ и $16,7 \pm 1,34$ соответственно). Следовательно, микроокружение селезенки не является
$\mathrm{BM}$ (see Fig. 2). It is known that during $12^{\text {th }}-16^{\text {th }}$ days of gestation FL is a main organ of hematopoiesis wherein expansion and differentiation of hematopoietic cells occur [4]. In this period liver contains a great number of long-term (LT-HSCs) and short-term hematopoietic cells (ST-HSCs), the activity of which is controlled by Steel factor, granulocyte-macrophage colonystimulating factor and interleukin-3 functioning in synergism [30,34]. High replicative potential of these cells, ability to differentiate into various hematopoietic lineages, prevent the death of lethally irradiated recipients are confirmed by numerous studies [19, 23, 29, 34]. Nevertheless, even with the same concentration of $\mathrm{CD} 34^{+} \mathrm{CD} 38^{-}$cells in native FL $((0.35 \pm 0.02) \%)$ and $\mathrm{BM}((0.30 \pm 0.04) \%)$ the colony-forming potential of FL was significantly lower than that of BM $(4.31 \pm 0.57$ and $16.7 \pm 1.34$, respectively). Therefore microenvironment of spleen is not an 'optimal' site to reveal functional activity of FL HSCs. Apparently subpopulation of BM cells forming colonies in spleen of lethally irradiated recipients is less potent than the one of FL cells.

In general terms, the HSCs with a potential to form colonies in vitro are more advanced in differentiation than CFUs [23]. The results of evaluation of their colony-forming activity after cryopreservation are presented in Fig. 4. Firstly, like for CFUs under all the cryopreservation regimens the CFU-GM content was lower than in native material. Secondly, peculiarities of changes in content of these hematopoietic functional units in FL and BM after utilization of certain regimen were the same as for CFUs. Maximum survival of fetal liver CFU-GM was provided by R3 as well. 
«оптимальным» сайтом для проявления функциональной активности СКК фетальной печени. Вероятно, что субпопуляция клеток КМ, формирующих колонии в селезенке летально облученных реципиентов, является менее потентной, чем ФП.

В общем, СКК с потенциалом формирования колоний в системе in vitro являются более продвинутыми в дифференцировке, чем КОЕс [27]. Результаты аттестации их колониеобразующей активности после криоконсервирования представлены на рис. 4. Во-первых, как и для КОЕс, при всех режимах криоконсервирования содержание КОЕ-ГМ было ниже, чем у нативного материала. Во-вторых, особенности изменения этих функциональных единиц гемопоэза в ФП и КМ при конкретном режиме были такие же, как и для КОЕс. Максимальную сохранность КОЕ-ГМ фетальной печени обеспечивал также Р3. Интересно, что при этих условиях достоверно увеличивался в 1,2 раза ИПА по сравнению с контролем, что свидетельствует о перераспределении предшественников в сторону более потентных КОЕ.

Характер изменения субпопуляционного состава КОЕ-ГМ в КМ и соответственно ИПА имел определенные отличия по сравнению с клетками ФП. Так, при криоконсервировании КМ более предпочтительными для колониеобразующего потенциала КОЕ-ГМ были Р2 и Р4, хотя последний не обеспечивал сбалансированного субпопуляционного состава (КОЕ и КлОЕ). Следует отметить, что колониеобразующая активность КОЕ-ГМ фетальной печени или костного мозга, криоконсервированных в определенном режиме, также совпадала с характером изменения КОЕс.

Неоднократно отмечалось, что СКК фетальных тканей имеют ряд существенных различий по сравнению с такими же клетками взрослого организма. Например, колониеобразующая активность СКК фетального КМ и кордовой крови превышала таковую взрослого КМ и периферической крови [21]. В исследованиях Y.Y. Ng и соавт. показаны функциональные отличия CD34+-клеток КМ и кордовой крови в системах in vitro и in vivo [24]. Установлено, что CD34+-клетки кордовой крови обладали лучшей и долгосрочной приживляемостью в организме реципиента. Кроме того, выявлены достоверные различия уровней экспрессии ключевых транскрипционных факторов, генов, играющих важную роль в процессах адгезии/миграции, пролиферации, дифференцировки, апоптоза клеток КМ, кордовой крови и генов, ассоциированных с клеточным циклом [24].

Проведенный нами сравнительный анализ структурно-функционального потенциала СКК фетальной печени и взрослого костного мозга
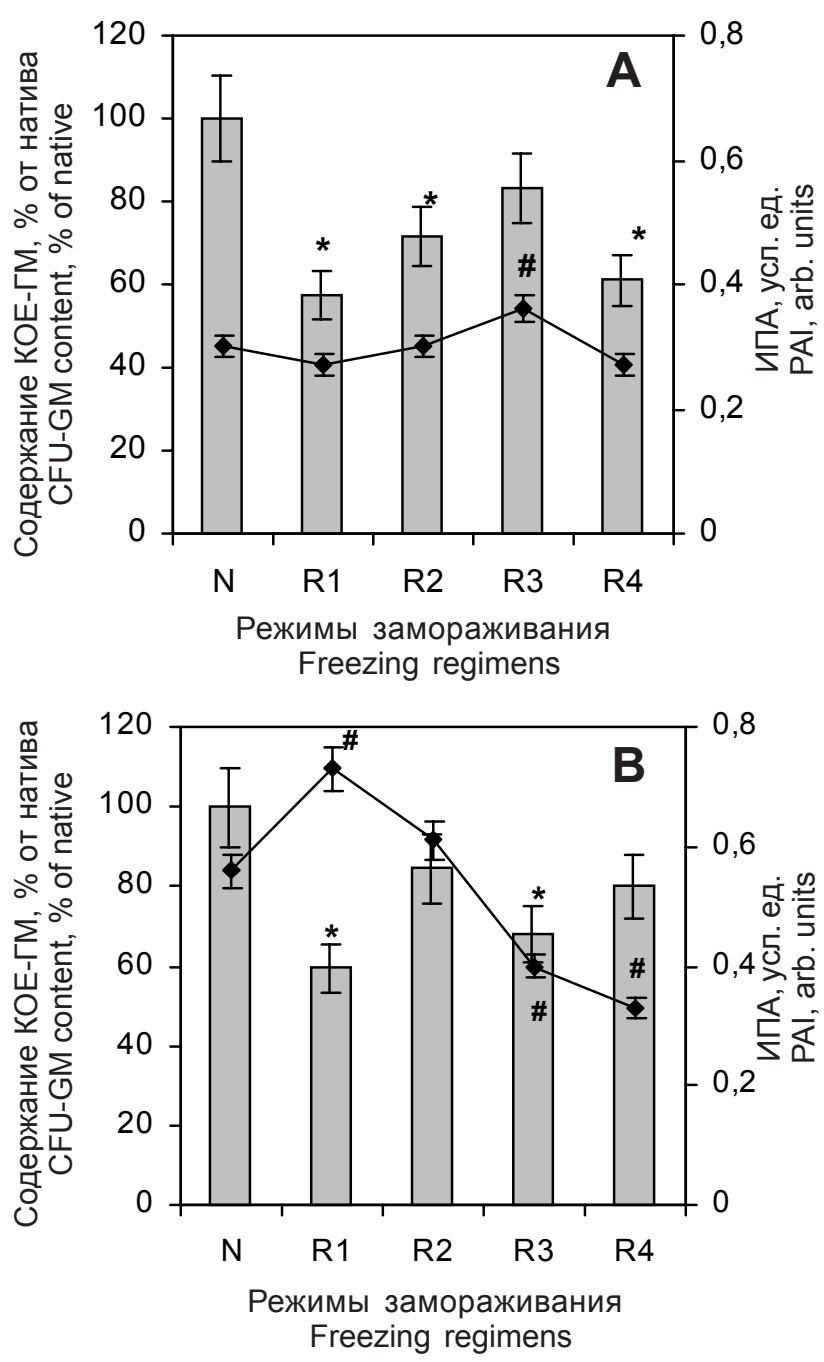

Рис. 4. Содержание КОЕ-ГМ (столбцы) и индекс пролиферативной активности (ИПА, линия) в ФП (А) и КМ (B) после криоконсервирования по разным режимам; R режим; N - натив; за 100\% принято количество колоний, формируемых нативными КОЕ-ГМ ФП и КМ; *, \# - различия значимы по отношению к соответствующему нативному контролю, $p<0,05$.

Fig. 4. Content of CFU-GM (columns) and proliferative activity index (PAI, line) in FL (A) and BM (B) after cryopreservation under different regimens; number of colonies formed by native CFU-GM of FL and BM were assumed as $100 \% ;{ }^{*}, \#$ - differences are significant in relation to the respective native control, $p<0.05$

Interestingly, that PAI increased 1.2 times under these conditions if compared with the control, indicating the redistribution of progenitors in favour of more potent CFUs.

Peculiarities of changes in CFU-GM subpopulation content in BM and subsequently PAI had certain differences if compared to FL cells. In particular, during cryopreservation of $\mathrm{BM}$ the more preferable for preserving the colony-forming potential of CFU-GM were R2 and R4, although the latter did not provide balanced subpopulation content (CFU and ClFU). It is 
показал не только различия их исходных качественно-количественных характеристик, но и разный ответ на действие факторов криоконсервирования. Принципиально важно, что использование такого методического подхода, как криоконсервирование, позволило подтвердить присутствие в ФП и КМ субпопуляций СКК разной степени дифференцировки, обладающих разной криочувствительностью.

Из полученных данных следует, что СКК, формирующие колонии in vivo (KОЕс) и in vitro (KОЕГМ), находятся в одной зоне криолабильности, но по-разному «отвечают» на каждый из четырех режимов криоконсервирования. Известно, что после криоконсервирования состояние клеток, оцененное по фенотипическим признакам не всегда совпадает с их функциональным статусом [18]. Следует отметить, что характер изменения колониеобразующей активности клеток стволового компартмента разного уровня дифференцировки (рис. 3,4$)$ в ФП и КМ не совпадал с содержанием $\mathrm{CD} 34^{+} \mathrm{CD} 38^{-}$-клеток (см. рис. 2). После криоконсервирования в P3 концентрация CD $34^{+} \mathrm{CD} 38^{-}-$ клеток ФП и их СИФ увеличивались (см. рис. 2, А), а содержание в ней КОЕс и КОЕ-ГМ снижалось по сравнению с нативным материалом. Использование Р2 приводило к снижению как количества $\mathrm{CD} 34^{+} \mathrm{CD} 38^{-}$-клеток, так и колониеобразующего потенциала ФП. Несмотря на повышенное содержание $\mathrm{CD} 34^{+} \mathrm{CD} 38^{-}$-клеток (см. рис. 2, В), в КМ после замораживания во всех режимах уменьшалось содержание КОЕс и КОЕ-ГМ по сравнению с нативным контролем (см. рис. 3,4$)$. Вместе с тем на фоне некоторого уменьшения количества ядросодержащих клеток в суспензиях ФП и КМ P2 и P3 способствовали селективному их обогащению клетками с фенотипом СКК (см. рис. 2) и обеспечивали достаточное сохранение функционально активных КОЕс и КОЕ-ГМ, ответственных за реализацию терапевтического потенциала исследуемого материала.

После выхода из состояния глубокого холодового анабиоза в кроветворных предшественниках развиваются нелетальные повреждения, вызывающие временное ингибирование их функционального потенциала $[8,18]$. Полученные данные о криочувствительности соматических тканеспецифических стволовых клеток свидетельствуют о том, что в их иерархической лестнице существуют предшественники, отличающиеся уровнем дифференцировки и функциональным статусом, что может определять разный «ответ» стволовых клеток на физикохимические факторы криоконсервирования. Например, в работе Е.А. Порожан и соавт. проведена оценка фенотипических характеристик фетальных worth to note that colony-forming activity of fetal liver or bone marrow CFU-GM cryopreserved under certain regimen was also consistent with the peculiarities of CFUs content changes.

Fetal tissue HSCs were repeatedly mentioned to have some significant changes as compared to the same cells of adult organism. For example, colonyforming activity of fetal BM and cord blood HSCs exceeded the one of adult BM and peripheral blood [15]. Studies of $\mathrm{Ng} \mathrm{Y.Y.} \mathrm{et} \mathrm{al.} \mathrm{showed} \mathrm{functional}$ differences of BM and cord blood $\mathrm{CD} 34^{+}$cells in vitro and in vivo [20]. It was established that $\mathrm{CD}^{+} 4^{+}$cells of cord blood had better and long-lasting grafting in the recipient's organism. In addition, a significant differences were revealed in expression level of transcription factors and genes that participate significantly in adhesion/migration, proliferation, differentiation, apoptosis of cells of BM, cord blood and genes associated with a cell cycle [19].

The performed by us comparative analysis of structural and functional potential of fetal liver and adult bone marrow HSCs showed the differences of their initial qualitative and quantitative characteristics as well as various response to the effect of cryopreservation factors. It is crucial that the use of such a methodical approach as cryopreservation enabled confirming the presence in FL and BM of HSC populations of various differentiation levels and possessing different cryosensitivity.

The data obtained show that HSCs forming colonies in vivo (CFUs) and in vitro (CFU-GM) are in the same zone of cryolability, but 'response' in a different way to the each of the four cryopreservation regimens. It is known that following cryopreservation the cell state assessed by phenotypic characteristics is not always consistent with their functional status [5]. It should be noted that the way of changing of colonyforming activity in stem cells of various differentiation level (Fig. 3, 4) in FL and BM did not coincide with the content of $\mathrm{CD} 34^{+} \mathrm{CD} 38^{-}$cells (see Fig. 2). After cryopreservation according $\mathrm{R} 3$ the concentration of CD34 ${ }^{+} \mathrm{CD} 38^{-}$and MFI of FL cells increased (Fig. 2A), and the content of CFUs and CFU-GM in it decreased as compared with the native specimens. Using R2 reduced both the number of $\mathrm{CD} 34^{+} \mathrm{CD} 38^{-}$cells and colony-forming potential of FL. Despite of an enhanced content of $\mathrm{CD}^{3} 4^{+} \mathrm{CD} 38^{-}$cells (Fig. 2B) in BM after freezing according all the regimens the content of CFUs and CFU-GM decreased as compared with the native control (Fig. 3, 4). Nevertheless, on the background of a slight decrease of nucleated cells content in suspensions of FL and BM, the utilization of R2 and R3 contributed to their selective enrichment with cells of HSCs phenotype (Fig. 2) and provided sufficient preservation of functionally active CFUs and CFU-GM 
нервных клеток 11 суток гестации и установлен факт большей криостабильности клеток с фенотипом CD133+ и nestin ${ }^{+}$, которые являются наименее дифференцированной популяцией [11]. A. Rubinshtein и F. Trobaug более 30 лет назад показали, что после замораживания-отогрева суспензия миелокариоцитов «обогащается» СКК, что обусловлено гибелью, в первую очередь, клеток КМ, находящихся на терминальной стадии дифференцировки [30]. На модели аденокарциномы Эрлиха было продемонстрировано, что стволовые раковые клетки поздних стадий развития более криочувствительны по сравнению с нативными образцами, а также криоконсервированными клетками более ранних сроков гестации [7]. Полученные нами результаты свидетельствуют о возможности использования криоконсервирования не только как метода долгосрочного хранения биообъекта, но и как управления его внутренним состоянием (intrinsic state).

\section{Выводы}

Продемонстрирована разная криоустойчивость СКК фетальной печени и взрослого костного мозга в завимости от режима замораживания. Сопоставление функциональных параметров (КОЕс и КОЕГМ) и фенотипических маркеров (CD34 и CD38) показало, что «оптимальным» режимом для клеток ФП является Р3, а для КМ - Р2. Установлено, что при варьировании условий криоконсервирования можно изменять функциональный потенциал СКК из разных источников.

Проведенные исследования являются актуальными как в теоретическом, так и прикладном аспектах с точки зрения оптимизации методов криоконсервирования и повышения терапевтического потенциала СКК.

\section{Литература}

1. Вермель А.Е. Стволовые клетки: общая характеристика и перспективы применения в клинической практике // Клин. медицина. - 2004. - №1. - С. 5-11.

2. Гольцев А.Н., Дубрава Т.Г., Гаевская Ю.А. и др. Криобиологические технологии как компонент оптимизированных методов лечения аутоиммунных заболеваний // Клін. імунол. алергол. інфектол. - 2009. - Т. 20-21, №1-2. - С. 46-51.

3. Гольцев А.Н., Дубрава Т.Г., Луценко Е.Д. и др. Поиск альтернативных криоконсервированию путей модификации иммунореактивности алломиелотрансплантата. II. Возможность сотрансплантации клеток эмбриональной печени // Проблемы криобиологии. - 2000. - №1. - С.10-21.

4. Гольцев А.Н., Дубрава Т.Г., Останкова Л.В. и др. Особенности влияния криоконсервирования на функциональный потенциал стволовых кроветворных клеток фетальной responsible for implementing the therapeutic potential of the studied material.

After leaving the deep cold hibernation the hematopoietic progenitors had non-lethal damages causing temporary inhibition of their functional potential are developed $[3,5]$. The findings about cryosensitivity of somatic tissue-specific stem cells attested that their hierarchy system included the progenitors varying by differentiation level and functional status that might determine a different 'response' of stem cells to physical and chemical factors of cryopreservation. For example, the study of Porozhan et al. reported the assessment of phenotypic characteristics of fetal neural cells of 11 gestation days and the fact of higher cryostability of the cell with $\mathrm{CD}_{13}{ }^{+}$and nestin ${ }^{+}$ phenotype being the least differentiated population [24]. Rubinstein and Trobaug showed more than 30 years ago that following freeze-thawing the suspension of myelocariocytes was 'enriched' with HSCs that was caused by death, primarily of BM cells, being at the terminal stage of differentiation [27]. Using the model of Ehrlich's carcinoma it was demonstrated that cancer stem cells of late development stages were more cryosensitive as compared to the native samples and cryopreserved cells of earlier gestation terms [13]. The obtained by us results testify to the possible use of cryopreservation not only as method for long-term storage of biological object, but also for controlling its intrinsic state.

\section{Conclusions}

Different cryosensitivity of fetal liver and adult bone marrow HSCs depending on the freezing regimen was demonstrated. Comparison of functional parameters (CFUs and CFU-GM) and phenotype markers (CD34 and CD38) showed that $\mathrm{R} 3$ was an 'optimal' regimen for FL cells, and R2 did for BM. We have found that varying cryopreservation conditions could change functional potential of HSCs derived from different sources.

The conducted experiments are relevant both theoretically and practically due to the need of optimization of cryopreservation methods and improvement of HSC therapeutic potential.

\section{References}

1. Burdon T.J., Paul A., Noiseux N. et al. Bone marrow stem cell derived paracrine factors for regenerative medicine: current perspectives and therapeutic potential. Bone Marrow Research 2011; 2011. Article ID 207326.

2. Catacchio I., Berardi S., Reale A. et al. Evidence for bone marrow adult stem cell plasticity: properties, molecular mecha- 
печени разных сроков гестации // Проблемы криобиологии. - 2009. - Т. 19, №2. - С. 186-199.

5. Гольцев А.Н., Мацевитая И.Ю., Луценко Е.Д. и др. К вопросу модификации иммунореактивности миелотрансплантата после криоконсервирования // Проблемы криобиологии. - 2010. - Т. 20, №2. - С. 145-152.

6. Гольцев А.Н., Останкова Л.В., Дубрава Т.Г. и др. Криоконсервирование как фактор модификации структурнофункционального состояния и механизма реализации лечебного эффректа клеток стволового компартмента в условиях развития патологий аутоиммунного генеза // Актуальные проблемы криобиологии и криомедицины / Под. ред. А.Н. Гольцева. - Харьков, 2012. - С. 543-551.

7. Гольцев А.М., Сафранчук О.В., Бондарович М.О. та ін. Зміна кріолабільності стовбурових пухлинних клітин залежно від фази росту аденокарциноми // Фізіол. журн. - 2011. Т. 57, №4. - С. 68-76.

8. Дубрава Т.Г. Эффективность криоконсервирования кроветворных клеток в зависимости от их исходных свойств: автореф. дис. ... канд. биол. наук. - Харьков, 1986. - 14 с

9. Козлова Ю.А., Гольцев А.Н., Останков М.В. Влияние изолированных физико-химических факторов криоконсервирования на клетки костного мозга с различным исходным статусом // Проблемы криобиологии. - 2003. - №4 - С. 3 11.

10.Луценко Е.Д. Использование пеннинг-метода для получения обогащенных стволовыми клетками популяций из криоконсервированного костного мозга // Проблемы криобиологии. - 1995. - № 4. - С. 52-54.

11.Порожан Е.А., Останков М.В., Бабенко Н.Н., Гольцев А.Н. Оценка фенотипических характеристик фетальных нервных клеток после криоконсервирования с использованием различных режимов замораживания // Проблемы криобиологии. - 2012. - Т. 22, №1. - С. 39-48.

12.Шерешков С.И. Культивирование гемопоэтических клеток на полутвердых питательных средах // Лаб. дело. 1974. - №3. - С. 146-150.

13.Ямпольская Е.Е., Гольцев А.Н., Гурина Т.М. Изменение функционального потенциала клеток фетальной печени в зависимости от режима криоконсервирования // Світ медицини та біології. - 2007. - №1. - С. 89-93.

14.Пат. №58203, Україна, МПК А61В5/00. Спосіб оцінки стану імунокомпетентної сфери організму / Гольцев А.М., Луценко О.Д., Дубрава Т.Г. и др.; заявл. 03.08.2010; опубл. 11.04.2011, Бюл. №7.

15.Burdon T.J., Paul A., Noiseux N. et al. Bone marrow stem cell derived paracrine factors for regenerative medicine: current perspectives and therapeutic potential // Bone Marrow Research. - 2011. - Vol. 2011. - ID 207326, 14 p.

16.Catacchio I., Berardi S., Reale A. et al. Evidence for bone marrow adult stem cell plasticity: properties, molecular mechanisms, negative aspects, and clinical applications of hematopoietic and mesenchymal stem cells transdifferentiation // Stem Cells International. - 2013. - Vol. 2013. - ID 589139, 11 p.

17.Ema H., Nakauchi $H$. Expansion of hematopoietic stem cells in the developing liver of a mouse embryo // Blood. - 2000. Vol. 95, №7. - P. 2284-2288.

18.Goltsev A. N., Babenko N. N., Dubrava T. G. et al. Modification of the state of bone marrow hematopoietic cells after cryopreservation // Int. J. Refrig. - 2006. - Vol. 29, №3. - P. 358-367.

19.Goltsev A.N., Grischenko V.I., Sirous M.A. et al. Cryopreservation: an optimizing factor for therapeutic potential of fetoplacental complex products // Biopreservation and Biobanking. 2009. - Vol. 7, №1. - P. 29-38.

20. Hattori Y., Kato H., Nitta M., Takamoto S. Decrease of L-selectin expression in human $\mathrm{CD} 34^{+}$cells on freeze-thawing and rapid recovery with short-term incubation // Exp. Hematol. - 2001. Vol. 29, №1. - P. 114-112.

21. Huang S., Law P., Ho A.D. Candidate hematopoietic stem cells from fetal tissues, umbilical cord blood vs. adult bone marrow nisms, negative aspects, and clinical applications of hematopoietic and mesenchymal stem cells transdifferentiation. Stem Cells Int 2013; 2013. Article ID 589139.

3. Dubrava T.G. Efficiency of hematopoietic cell cryopreservation depending on their initial properties [dissertation]. Kharkov; 2005.

4. Ema H., Nakauchi H. Expansion of hematopoietic stem cells in the developing liver of a mouse embryo. Blood 2000; 95(7): 2284-2288.

5. Goltsev A.N., Babenko N.N., Dubrava T.G. et al. Modification of the state of bone marrow hematopoietic cells after cryopreservation. Int J Refrigeration 2006; 29(3): 358-367.

6. Goltsev A.N., Dubrava T.G., Gayevskaya Yu.A. et al. Cryobiological technologies as a component of optimized methods in therapy of autoimmune diseases. Klin Imunol Alergol Infektol 2009; (1-2): 46-51.

7. Goltsev A.N., Dubrava T.G., Lutsenko E.D., et al. Search for the alternative to cryopreservation methods of modifing the immunereactivity of the allomyelotransplant. II. Possible cotransplantation of embryonic liver cells. Problems of Cryobiology 2000; (1): 10-21.

8. Goltsev A.N., Dubrava T.G., Ostankova L.V., et al. Peculiarities of cryopreservation effect on functional potential of fetal liver hemopoietic stem cells of various gestation terms. Problems of Cryobiology 2009; 19(2): 186-199.

9. Goltsev A.N., Grischenko V.I., Sirous M.A. et al. Cryopreservation: an optimizing factor for therapeutic potential of fetoplacental complex products. Biopreservation and Biobanking 2009; 7(1): 29-38.

10.Goltsev A.N., Lutsenko Ye.D., Dubrava T.G. et al. Method of assessing state of organism's immune competence. Patent of Ukraine 58203, IPC A61B5/00. 2011 Apr11

11.Goltsev A.N., Matsevitaya I.Yu., Lutsenko Ye.D., et al. On the modification of immunoreactivity of myelotransplant after cryopreservation. Problems of Cryobiology 2010; 20(2): 145-152.

12.Goltsev A.N., Ostankova L.V., Dubrava T.G. et al. Cryopreservation as the factor of modification of structural and functional state and the realization mechanism of therapeutic effect of compartment stem cells under autoimmune genesis pathology development. In: Goltsev A.N., editor. Current problems of cryobiology and cryomedicine. Kharkov; 2012. p. 543-551.

13.Goltsev A.N., Safranchuk O.V., Bondarovich M.O. et al. Change in cryolability of stem tumor cells depending on adenocarcinoma growth phase. Fiziol Zhurnal 2011; 57(4): 68-76.

14. Hattori Y., Kato H., Nitta M., Takamoto S. Decrease of L-selectin expression in human $\mathrm{CD} 34^{+}$cells on freeze-thawing and rapid recovery with short-term incubation. Exp Hematol 2001; 29(1): 114-112.

15. Huang S., Law P., Ho A.D. Candidate hematopoietic stem cells from fetal tissues, umbilical cord blood vs. adult bone marrow and mobilized peripheral blood. Exp Hematol 1998; 26(12): 1162-1171.

16.Kozlova Yu.A., Goltsev A.N., Ostankov M.V. Influence of certain physical and chemical factors of cryopreservation on bone marrow cells with various initials structural an functional status. Problems of Cryobiology 2003; (4): 3-11.

17.Ljungman P., Bregni M., Brune M. et al. Allogeneic and autologous transplantation for haematological diseases, solid tumours and immune disorders: current practice in Europe 2009. Bone Marrow Transplant 2010; 45(2): 219-234.

18.Lutsenko E.D. Application of penning-methods for obtaining enriched stem cells of population from cryopreserved bone marrow. Problems of Cryobiology 1995; (4): 52-54.

19.Micklem H.S., Ford C.E., Evans E.P. et al. Competitive in vivo proliferation of foetal and adult haematopoietic cells in lethally irradiated mice. J Cell Physiol 1972; 79(2): 293-298.

20.Ng Y.Y., van Kessel B., Lokhorst H.M. et al. Gene-expression profiling of $\mathrm{CD}_{3} 4^{+}$cells from various hematopoietic stem-cell sources reveals functional differences in stem-cell activity. J Leukoc Biol 2004; 75(2): 314-323. 
and mobilized peripheral blood // Exp. Hematol.- 1998.- Vol. 26, №12. - P. 1162-1171.

22.Ljungman P., Bregni M., Brune M. et al. Allogeneic and autologous transplantation for haematological diseases, solid tumours and immune disorders: current practice in Europe 2009 // Bone Marrow Transplant. - 2010. - Vol. 45, №2. P. 219-234.

23.Micklem H.S., Ford C.E., Evans E.P. et al. Competitive in vivo proliferation of foetal and adult haematopoietic cells in lethally irradiated mice // J. Cell Physiol. - 1972. - Vol. 79, №2. P. 293-298.

24. Ng Y.Y., van Kessel B., Lokhorst H.M. et al. Gene-expression profiling of $\mathrm{CD} 34^{+}$cells from various hematopoietic stem-cell sources reveals functional differences in stem-cell activity // J. Leukoc. Biol. - 2004. - Vol. 75, №2 - P. 314-323.

25.Nielsen J.S., McNagny K.M. Novel functions of the CD34 family // J. Cell Sci. - 2008. - Vol. 121. - P. 3682-3692.

26.Ojeda-Uribe M. Peripheral blood and BM CD $34^{+} \mathrm{CD} 38^{-}$cells show better resistance to cryopreservation than $\mathrm{CD} 34^{+} \mathrm{CD} 38^{+}$ cells in autologous stem cell transplantation // Cytotherapy. 2004. -Vol. 6, №6. - P. 571-583.

27. Orkin S.H., Nathan D.G., Ginsburg D. et al. Nathan and Oski's hematology of infancy and childhood. - Philadelphia: Elsevier, 2009. - $1841 \mathrm{p}$.

28.Rosillo M.C., Ortuco F., Rivera J., Moraleda J.M, Vicente V. Cryopreservation modifies flow-cytometric analysis of hemopoietic cells // Vox Sang. - 1995. - Vol. 68, №4. - P. 210-214.

29.Rowley S.D., Bensinger W.I., Gooley T.A. Effect of cell concentration on bone marrow and peripheral blood stem cell cryopreservation // Blood. - 1994. - Vol. 83, №9. - P. 2731 2736.

30.Rubinshtein A., Trobaugh F. Ultrastructure of presumptive hematopoietic stem cells // Blood. - 1973. - Vol. 42, №1. P. 61-80.

31.Shizuru J.A., Negrin R.S., Weissman I.L. Hematopoietic stem and progenitor cells: clinical and preclinical regeneration of the hematolymphoid system // Annu. Rev. Med. - 2005. Vol. 56. - P. 509-538.

32. Suzuki A., Zheng Y., Kaneko S. et al. Clonal identication and characterization of self-renewing pluripotent stem cells in the developing liver // J. Cell Biol. - 2002. - Vol. 156, №1. P. 173-184.

33.Till J.E., McCulloch E.A. A direct measurement of the radiation sensitivity of normal mouse bone marrow cells // Radiat. Res. 1961. - Vol. 14. - P. 213-222.

34. Tyndall A., Gratwohl A. Hemopoietic blood and marrow transplants in the treatment of severe autoimmune disease // Curr. Opin. Hematol. - 1997. - Vol. 4, №6. - P. 390-394.

35.Wu D.D., Nayar R., Keating A. Synergistic effect of stem cell factor with interleukin-3 or granulocyte-macrophage colonystimulating factor on the proliferation of murine primitive hematopoietic progenitors // Exp. Hematol. - 1994. - Vol. 22, №6. - P. 495-500.
21.Nielsen J.S., McNagny K.M. Novel functions of the CD34 family. J Cell Sci 2008; 121: 3682-3692.

22. Ojeda-Uribe M. Peripheral blood and BM CD34+ ${ }^{+} \mathrm{CD} 38^{-}$cells show better resistance to cryopreservation than $\mathrm{CD} 34^{+} \mathrm{CD} 38^{+}$ cells in autologous stem cell transplantation. Cytotherapy 2004; 6(6): 571-583.

23.Orkin S.H., Nathan D.G., Ginsburg D. et al., editors. Nathan and Oski's hematology of infancy and childhood. Philadelphia: Elsevier; 2009.

24.Porozhan Ye.A., Ostankov M.V., Babenko N.N., Goltsev A.N. Assessment of phenotype characteristics of fetal neural cells after cryopreservation using different freezing regimens. Problems of Cryobiology 2012; 22(1): 39-48.

25.Rosillo M.C., Ortuco F., Rivera J., Moraleda J.M, Vicente V. Cryopreservation modifies flow-cytometric analysis of hemopoietic cells. Vox Sang 1995; 68(4): 210-214.

26.Rowley S.D., Bensinger W.I., Gooley T.A. Effect of cell concentration on bone marrow and peripheral blood stem cell cryopreservation. Blood 1994; 83(9): 2731-2736.

27.Rubinshtein A., Trobaugh F. Ultrastructure of presumptive hematopoietic stem cells. Blood 1973; 42(1): 61-80.

28. Shereshkov S.I. Culturing of hematopoietic cells on semisolid nutrient media. Lab Delo 1974; (3): 146-150.

29.Shizuru J.A., Negrin R.S., Weissman I.L. Hematopoietic stem and progenitor cells: clinical and preclinical regeneration of the hematolymphoid system. Annu Rev Med 2005; 56: 509538.

30.Suzuki A., Zheng Y., Kaneko S. et al. Clonal identication and characterization of self-renewing pluripotent stem cells in the developing liver. J Cell Biol 2002; 156(1): 173-184.

31. Till J.E., McCulloch E.A. A direct measurement of the radiation sensitivity of normal mouse bone marrow cells. Radiat Res 1961; 14: 213-222.

32.Tyndall A., Gratwohl A. Hemopoietic blood and marrow transplants in the treatment of severe autoimmune disease. Curr Opin Hematol 1997; 4(6): 390-394.

33.Vermel A.E. Stem cells: total characteristic and application perspectives in clinical practice. Klin Meditsina 2004; (1): 511.

34.Wu D.D., Nayar R., Keating A. Synergistic effect of stem cell factor with interleukin-3 or granulocyte-macrophage colonystimulating factor on the proliferation of murine primitive hematopoietic progenitors. Exp Hematol 1994; 22(6): 495-500.

35.Yampolskaya K.Ye., Goltsev A.N., Gurina T.M. Change in functional potential of fetal liver cells dependent from cryopreservation regimen. Svit Meditsiny i Biologii 2007; (1): 89-93. 